\title{
Ectoparasite inventorisation of nilem fish (Osteochilus hasselti) fingerlings cultured on ponds in Sukabumi, West Java, Indonesia
}

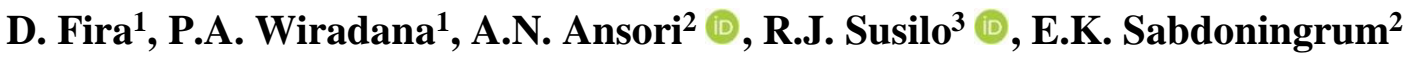 \\ ${ }^{1}$ Faculty of Fisheries and Marine Science, ${ }^{2}$ Faculty of Veterinary Medicine, ${ }^{3}$ Faculty of Science and Technology, University \\ of Airlangga, Surabaya, Indonesia
}

\begin{tabular}{l} 
Article information \\
\hline Article history: \\
Received May 02, 2020 \\
Accepted June 26, 2020 \\
Available online June 28, 2021 \\
\hline Keywords: \\
Osteochilus hasseltii \\
Sukabumi \\
Ectoparasites
\end{tabular}

Correspondence:

E.K. Sabdoningrum

emy-k-s@fkh.unair.ac.id

\begin{abstract}
Nilem fish (Osteochilus hasseltii) is a type of freshwater fish native to Indonesia that is included in the Cyprinid family and has the potential to be developed as a superior product of aquaculture in Indonesia. This study aims to inventorisation the level of ectoparasite in nilem fish fingerlings cultured on the ponds in Sukabumi, West Java, Indonesia. Ectoparasites examination was carried out by taking mucus from the skin surface and gill of nilem fish. Sample preparations that have been made are observed using a stereomicroscope. Prevalence and intensity levels were analyzed by descriptive analysis. The observation of the sample showed the presence of ectoparasites such as Trichodina sp. P: 86.67\%; MI: 7.69 ind/fish and Dactylogyrus sp. P: 6.67\%; MI: 1 ind/fish. In summary, the level of prevalence and intensity produced are included in the medium category infestation and the two parasites found cannot pose a zoonotic risk.
\end{abstract}

DOI: 10.33899/ijvs.2020.127031.1440, (\$2021, College of Veterinary Medicine, University of Mosul.

This is an open access article under the CC BY 4.0 license (http://creativecommons.org/licenses/by/4.0/).

\section{Introduction}

Indonesia is the second largest fish producer in the world after China, with capture fisheries and aquaculture production, estimated at 6.5 and 14.4 million tons, respectively in 2014. The fisheries sector plays an important role in Indonesia's economy through income generation, livelihoods diversification, supply of animal proteins, and foreign exchange earnings. In addition, fish supply in Indonesia has been growing at a steady rate over the past 50 years, from 0.8 million tons in 1960 to 10.7 million tons in 2014 (1). Nilem fish (Osteochilus hasseltii) is a type of freshwater fish native to Indonesia and belongs to the Cyprinid family which has the potential to be developed as a superior aquaculture product in Indonesia (2). This fish is often cultivated in traditional ponds to intensive systems based on concrete ponds (3). Nilem fish is often used by people in West Java as processed food products (2). Nilem fish eggs can also be developed as an export commodity (4).
Nilem fish has fatty acids of saturated fatty acid (11.86\%), monounsaturated fatty acids $(15.36 \%)$, and polyunsaturated fatty acids $(9.38 \%)$ and fatty acids content of nilem fish in the form of dodecanoic acid, pentadecanoic acid, 9hexadecenoic acid, 9,9-octadecadienoic acid, 9octadecenoic acid, and 9,9,15-octane acid close to the linolenic acid (5). Seeing the high content of fatty acids from the fish nilem fish is very good to be consumed as a daily food supplement. Based on the nutrition of the nilem fish, farmers try to increase stocking density to get high production yields to meet market needs. However, the application of nilem fish culture with high stocking density can increase the risk of stress due to the high sensitivity of nilem fish to environmental stress (6-8). Nilem fish are often cultivated semi-intensive in traditional ponds and are often combined with other types of fish such as tilapia, carp, koi, and tawes (9). Decreased production of nilem fish can be caused by parasitic, bacterial, and fungal infections (2). Until now, research on the types of ectoparasites that infect nilem 
fish fingerlings cultivated in traditional ponds is still not widely known. Ectoparasite infestation is one of the main problems associated with fish farming in ponds. Ectoparasites including protozoa, monogenetic trematodes, and crustaceans have a life cycle that is directly translocated from the host and is capable of causing mass death due to its development (10). Parasitic infections that occur can cause a decrease in the production of nilem fish fingerlings so that it has an impact on the decline in aquaculture production.

Based on this, this study aims to monitor the type, prevalence level, and intensity of ectoparasites as well as treatment efforts on the seeds of nilem fish infected by parasites.

\section{Materials and methods}

\section{Fish sampling location}

This study was conducted in the rainy season in early 2019 for 2 months (January to February 2019). Sampling was carried out in a traditional pond with an area of $2 \times 3 \mathrm{~m}$ with a depth of $50 \mathrm{~cm}$. The number of seeds of nilem fish is 15 fingerlings (length $3.68 \pm 0.88 \mathrm{~cm}$ ) collected from ponds in Sukabumi, West Java and put into plastic containers equipped with ice and then transported to the Aquatic Animal Health Laboratory, Main Center of Freshwater Aquaculture, Sukabumi, West Java, Indonesia $\left(6^{\circ} 55^{\prime} 05^{\prime \prime} \mathrm{S}\right.$ $\left.106^{\circ} 55^{\prime} 53^{\prime \prime} \mathrm{E}\right)$ (Figure 1).

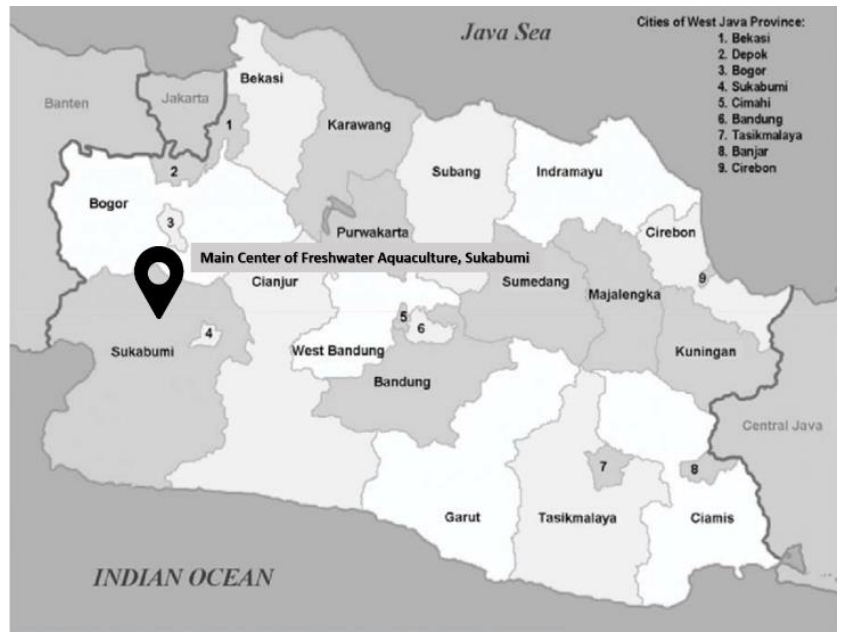

Figure 1: Location of sampling for nilem fish (O. hasseltii) in Sukabumi, West Java, Indonesia.

\section{Ectoparasites preparation and examination}

Sample preparation was done by separating the gills organs of the nilem fish fingerlings. Ectoparasites were carried out by the native method (11). The tool used for scrapping was a sterile scalpel by scraping slowly on the surface of the body from the anterior end of the head to the posterior caudal fins. The scrapping results were placed on the Petri dish and dropped with distilled water which was then microscopically examined. Gill examination was done by cutting the gills using surgical scissors and the gills were placed on a Petri dish to be dropped with distilled water and then microscopically examined. Preparations that had been made are then observed using a stereomicroscope at 40-100x magnification (SZX10, Olympus) and documented using an Optilab camera. The results obtained were identified based on instructions (12). Water quality parameters observed in this study include dissolved oxygen (DO) using a DO meter (YSI model $550 \mathrm{~A}$ ), water temperature using digital thermometer, $\mathrm{pH}$ using a $\mathrm{pH}$ meter (Eutech pHTestr 20), salinity using a refractometer (Atago 2473 MASTERS10M), and NH3 using the Ammonia Test Kit (Salifert Ammonia Marine Test Kit).

\section{Data analysis}

The data obtained in the form of pictures, tables, and graphs were then analyzed descriptively by analysis to determine the prevalence $(\mathrm{P})$ value and mean intensity (MI) of the ectoparasites that had been found. P and MI level calculations are based on through the following formula, prevalence $(\%)=$ number of infected fish/number of fish examined $* 100$, and the intensity $=$ number of parasites found in the sample/number of fish infested with parasites. The infection status that occurs in nilem fish can be determined after qualitatively categorizing based on method as shown in table 1 and $2(12,13)$.

Table 1: Categories of ectoparasite prevalence levels according to (12)

\begin{tabular}{lc}
\hline Rate of infection & Prevalence \\
\hline Always & $100-99 \%$ \\
Almost always & $98-90 \%$ \\
Usually & $89-70 \%$ \\
Very often & $69-50 \%$ \\
Generally & $49-30 \%$ \\
Often & $29-10 \%$ \\
Sometimes & $9-1 \%$ \\
Rarely & $<1-0.1 \%$ \\
Very rarely & $<0.1-0.01 \%$ \\
Almost never & $<0.01 \%$ \\
\hline
\end{tabular}

Table 2: The intensity level of ectoparasitic infection according to (12)

\begin{tabular}{lc}
\hline Infection rate & Intensity (ind/fish) \\
\hline Very low & 1 \\
Low & $1-5$ \\
Medium & $6-55$ \\
Severe & $51-100$ \\
Awfully & $>100$ \\
Super infection & $>1000$ \\
\hline
\end{tabular}




\section{Results}

The results of this study are that two types of ectoparasites infect nilem fish fingerlings during observation, namely Trichodina sp. and Dactylogyrus sp. with prevalence respectively $(86.67 \% / 6.67 \%)$ and with the MI category is medium for Trichodina sp. and low MI for Dactylogyrus sp. (Table 3).

The results from ponds water quality showed a dissolved oxygen (DO) value of $8.0 \mathrm{mg} / \mathrm{L}$, a temperature of $25.5^{\circ} \mathrm{C}$, a $\mathrm{pH}$ of 7.9, and $\mathrm{NH}_{3}$ ranging from 0.05-0.10 ppm (Table 4).

Table 3: Prevalence Level (P) and Mean Intensity (MI) in nilem fish fingerlings cultivated in ponds

\begin{tabular}{lcccc}
\hline Parasite & $\begin{array}{c}\text { Gill } \\
\mathrm{s}\end{array}$ & $\begin{array}{c}\text { Body } \\
\text { surfac } \\
\mathrm{e}\end{array}$ & $\mathrm{P}(\%)$ & $\begin{array}{c}\text { MI } \\
\text { (ind/fish) }\end{array}$ \\
\hline $\begin{array}{l}\text { Trichodina } \\
\text { Dactylogyru }\end{array}$ & 50 & 50 & 86.67 & 7.69 \\
$s$ Total & 1 & - & 6.67 & 1 \\
\hline & 51 & 50 & $\begin{array}{c}46.67 \pm 56.5 \\
6\end{array}$ & $\begin{array}{c}4.34 \pm 4.7 \\
3\end{array}$ \\
\hline
\end{tabular}

Notes: P: Prevalence; MI: Mean Intensity.

Table 4: Results of measurements of water quality in nilem ponds in Sukabumi, West Java, Indonesia

\begin{tabular}{lc}
\hline Parameter & Result \\
\hline Temperature & $25.5^{\circ} \mathrm{C}$ \\
pH & 7.9 \\
DO (Dissolve oxygen) & $8.0 \mathrm{mg} / \mathrm{L}$ \\
Salinity & $0 \mathrm{ppt}$ \\
$\mathrm{NH}_{3}$ & $0.05-0.10 \mathrm{ppm}$ \\
\hline
\end{tabular}

\section{Discussion}

The prevalence and intensity values of ectoparasites which reached $89-70 \%$ and $<6-55$ ind/fish showed that the level of parasitic infections in nilem fish fingerlings was classified as usually and moderate infection and medium (13). The moderate infection and medium level of prevalence and intensity from Trichodina sp. caused by parasites ability to multiply rapidly and are always actively engaged in movement (14). Trichodina sp. is found in the skin and gills of fish. The parasite has an adhesive part that functions to stick to the host. This parasite is also equipped with cilia around the surface of the body and teeth on the inside that can be used to attach to host tissue. The intensity value of Trichodina sp. in the nilem fish fingerlings belonging to the Kutasari Purbalingga Fish Seed Center was 16.08 individuals/fish and it is included in the medium category ( $<6-55$ ind/fish), and the morphological identification of Trichodina sp. found included in the species T. acuta, T. heterodentata, and T. nobilis. Moreover, Trichodina spp species was more dominant to infect Cyprinidae fish groups such as nilem fish (15). Fries and fingerlings are very susceptible to parasites due to changes in the aquatic environment. Water quality parameters such as water temperature, $\mathrm{DO}, \mathrm{pH}$, and hardness are the four main water quality parameters associated with disease infections because they can fluctuate rapidly. In addition, the fingerlings phase requires more $\mathrm{O}_{2}$ levels and because of decreased $\mathrm{O}_{2}$ levels can make nilem fish more susceptible to infection. Increased tear density can also allow ectoparasite contamination from one fish to another so that it can be seen that water quality has a large impact on the abundance of pathogens and their ability to develop on hosts.

It could be seen that the number of Trichodina sp. found in this study was lower than gourami seeds that had been found before $(16,17)$. The intensity of the infection attack was Trichodina sp. on the seeds of nilem fish that were cultivated in Kutasari Purbalingga; Central Java had a value of $16.08 \mathrm{ind} / \mathrm{each}$ (15). Environmental factors and stocking density of fish greatly influence the number of infections on Trichodina sp. (18). Fish physiology can be disturbed due to high stocking density, nutritional deficiencies, and decreased water quality, which causes fish to become stressed and easily infected by pathogens (19). The existence of Trichodina sp. with a number of little or less than five organisms are not at risk for mortality of nilem fish, but if the fingerlings are kept in ponds with high stocking densities and poor water quality, these parasites will develop rapidly to cause increased mortality in fry (9). The influence of season is very influential on the prevalence of parasites. Prevalence data indicate that ectoparasitic infections will increase during winter and rain (October-January) so maintaining water quality during this season is very important.

The next parasite detected in this study was Dactylogyrus $\mathrm{sp}$, which is a specific parasite that develops on the gills and skin of fish. The parasite has a pair of hooks that can be hooked to the fish body surface, causing irritation, excessive mucus production, and creating open sores as an entry point for bacteria and other pathogens (20). The main target organ of this parasite is the gills so that many refer to this parasite as gill fluke in fish from the Cyprinidae family.

The presence of these parasites in healthy adult fish usually does not show significant infectious symptoms. However, if the increase in parasites occurs in fingerlings, it can cause very high mortality $(21,22)$. Nilem fish fingerlings that are more resistant to parasitic infections Dactylogyrus sp. when compared to carp and koi fingerlings (8). Efforts to overcome this parasite infestation can be done through the quarantine system by transferring infected fish or showing clinical symptoms into a special pond so as to prevent or break the chain of spread to other healthy fish $(23,24)$. Furthermore, using formalin and potassium permanganate can effectively control parasite infestations in freshwater fish. Dactylogyrus population is often found in the egg layer. 
Eggs that are sustainably given these chemicals, are more likely to be able to avoid the parasites (25).

Low pond temperatures can increase the prevalence of parasites in fish. Otherwise, if the temperature increases gradually $\left(27-32{ }^{\circ} \mathrm{C}\right)$, it will be able to reduce the risk of increased parasitic prevalence. Shallow and stagnant water can support the development of Trichodina. The existence of Trichodina sp. is always followed by Dactylogyrus sp. Both types of parasites are also found in carp farming in Malaysia, Sri Lanka, and Bangladesh. Thus, stocking density and water quality must be maintained to avoid infestation from these parasites, especially in nurseries.

\section{Conclusion}

The observation of the sample showed the presence of ectoparasites such as Trichodina sp. (P: 86.67\%; MI: 7.69 ind/fish) and Dactylogyrus sp. (P: 6.67\%; MI: 1 ind/fish). Based on the level of prevalence and intensity of the ectoparasites, this infestation can be categorized in usually and moderate infection and medium. This parasite also indicates no risk of zoonosis or transmission to different hosts including humans.

\section{Acknowledgment}

This study was supported by University of Airlangga and Main Center of Freshwater Aquaculture, Sukabumi, West Java, Indonesia.

\section{Conflict of interests}

The authors declare that they have no competing interests.

\section{References}

1. Tran N, Rodriguez UP, Chan CY, Phillips MJ, Mohan CV, Henriksson PJG, Koeshendrajana S, Suri S, Hall S. Indonesian aquaculture futures: An analysis of fish supply and demand in Indonesia to 2030 and role of aquaculture using the Asia fish model. Mar Policy 2017;79:25-32. DOI: 10.1016/j.marpol.2017.02.002.

2. Hasan V, Soemarno, Widodo MS, Wiadnya DGR. First record of Osteochilus vittatus (Cypriniformes: Cyprinidae) in Madura Island, Indonesia. Aquac Aquar Conserv Legis 2019;12(1):338-342.

3. Gangadhar B, Sridhar N, Hemaprasanth K, Raghunath M, Jayasankar $\mathrm{P}$. Indigenous technical knowledge in aquaculture sector: A literature review. Int J Fish Aquat Stud 2016;4(1):373-378.

4. Guimaraes RR, Vendramini ALD, dos Santos AC, Leite SGF, Miguel MAL. Development of probiotic beads similar to fish eggs. J Funct Foods 2013;5(2):968-973. DOI: 10.1016/j.jff.2013.01.002.

5. Boguslawska-Tryk M, Piotrowska A, Szymeczko R, Burlikowska K, Glowinska B. Lipid metabolism and fatty acids profile in the blood serum of broiler chickens fed a diet with lignocellulose. Braz J Poultry Sci 2016;18(3):451-456. doi.org/10.1590/1806-9061-2015-0157.

6. Alam MM, Khan MA, Hussain MA, Moumita D, Mazlan AG, Simon KD. Intensity of parasitic infestation in silver carp, Hypophthalmichthys molitrix. J Zhejiang Univ-Sci B 2012;13(12):1024-1028. DOI: 10.1631\%2Fjzus.B1200121.
7. Mofasshalin MS, Bashar MA, Alam MM, Alam GM, Moumita D, Mazlan AG, Simon KD. Parasites of three Indian minor carps of Rajshahi, Bangladesh. Asian J Anim Vet Adv 2012;7(7):613-620. DOI: 10.3923/ajava.2012.613.620.

8. Gao Y, He Z, Vector H, Zhao B, Li Z, He J, Lee J-Y, Chu Z. Effect of stocking density on growth, oxidative stress and HSP70 of pacific white shrimp Litopenaeus vannamei. Turk J Fish Aquat Sc 2017;17:877-884. DOI: 10.4194/1303-2712-v17_5_04.

9. Sarker S, Basak SC, Hasan J, Hossain MS, Rahman MM, Islam MA. Production in small scale aquaculture farm: A success story from Bangladesh. J Aquac Res Development 2017;8(10):1-7. DOI: 10.4172/2155-9546.1000515.

10. Al-Marjan, K.S.N., Abdullah, S.M.A. Some ectoparasites of the common carp (Cyprinus carpio) in Ankawa fish hatchery, Erbil province. J Duhok Univ 2009;12(1):102-107.

11. Trujillo-Gonzalez A, Constantinoiu CC, Rowe R, Hutson KS. Tracking transparent monogenean parasites on fish from infection to maturity. Int J Parasitol Wildl 2015;4(2015):316-322. DOI: 10.1016/j.ijppaw.2015.06.002.

12. Hoffman GL. Parasites of North American freshwater fishes. Ithaca and London: Comstock Publishing Associates; 1998. 539 p.

13. Fitriani EN, Rozi, Arief M, Suprapto H. Prevalence and intensity of ectoparasite in gabus fish (Channa striata) at Cangkringan Fishery Cultivation Technology Development Center, Sleman, Yogyakarta. IOP Conf Ser Earth Environ Sci 2019;236(2019):1-8. DOI: 10.1088/1755-1315/236/1/012095

14. Williams EH, Bunkley-Williams, L. Parasites of offshore big game fishes of Puerto Rico and the Western Atlantic. Rio Piedras: Department of Natural Environmental Resources, University of Puerto Rico; 1996. 382 p.

15. Steckert LD, Furtado WE, Jeronimo GT, Tancredo KR, Hashimoto GSD, Pereira SA, Martins ML. Hematological analysis and relative condition factor in naturally parasitized Nile tilapia. Lat Am J Aquat Res 2019;47(3):502-512. DOI: 10.3856/vol47-issue3-fulltext-12.

16. Riwidiharso E, Alfarisi B, Rokhmani. Morphology and intensity of Trichodina spp. in the nilem fish larvae (Osteochilus hasselti) hatchery fish by the Kutasari Purbalingga, Central Java. Pros Sem Nas Masy Biodiv Indon 2019;5(2):316-323.

17. Madsen H, Dung BT, The DT, Viet NK, Dalsgaard A, Van PT. The role of rice fields, fish ponds and water canals for transmission of fish-borne zoonotic trematodes in aquaculture ponds in Nam Dinh Province, Vietnam. Parasit Vectors 2015;8(625):1-11. DOI: 10.1186/s13071015-1237-z.

18. Rokhmani, Setyawati EA, Wahyono DJ. Molecular detection of protozoa Trichodina spp. in: Gourami (Osphronemus gourami Lac.) larvae with the infecting 18s rRNA gene marking in exs. Residence of Banyumas, Central Java. Biosaintifika 2018;10(2):320-325. DOI: 10.15294/biosaintifika.v10i2.11720.

19. Xu D-H, Shoemaker CA, Zhang D. Treatment of Trichodina sp reduced load of Flavobacterium columnare and improved survival of hybrid tilapia. Aquacult Rep 2015;2(2015):126-131. DOI: 10.1016/j.aqrep.2015.09.007.

20. Assefa A, Abunna F. Maintenance of fish health in aquaculture: review of epidemiological approaches for prevention and control of infectious disease of fish. Vet Med Int 2018;2018:1-10. DOI: $10.1155 / 2018 / 5432497$

21. Bentzon-Tilia M, Sonnenschein EC, Gram L. Monitoring and managing microbes in aquaculture-toward a sustainable industry. Microb Biotechnol 2016;9(5):576-584. DOI: 10.1111/17517915.12392.

22. Raissy M, Ansari, M. Parasites of some freshwater fish from Armand River, Chaharmahal va Bakhtyari Province, Iran. Iranian J Parasitol 2012;7(1):73-79.

23. Borji H, Naghibi A, Nasiri MR, Ahmadi A. Identification of Dactylogyrus spp. And other parasites of common carp in Northeast of Iran. J Parasit Dis 2012;36(2):234-238. DOI: 10.1007/s12639-0120115-2.

24. Hemaprasanth KP, Sridhar N, Raghuanth MR. Lernaea cyprinacea infection in a new host Puntius pulchellus in intensive culture system 
and its control by doramectin. J Parasit Dis 2017;41(1):120-127. DOI: 10.1007/s12639-016-0761-x.

25. Xiao-Ping Z, Bao-Di S, Gui-Tang W, Wen-Xiang L, Xing Y, ZhengYou L. The effects of temperature on egg laying, egg hatching and larval development of Dactylogyrus vastator. Acta Hydrobiol Sin 2015;39(6):1177-1182. DOI: 10.7541/2015.154

\section{جرد الطقيليات الخارجية في اصبعيات اسماك النيلم

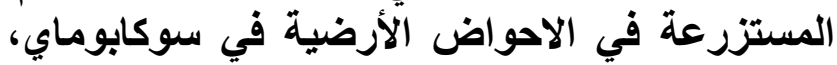 غرب جافا، اندونيسيا في الانيا}

دي فيرا، بي أي ويرادانا، أي إن أنسوري، آر جي سوسيلو، إي كي

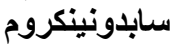

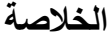

اسماك النيلم (Osteochilus hasselti) نوع من اسماك المياه العذبة المستوطنة في اندونيسيا من ضمن عائلة الثبوطيات ولها الها أهمية إنتاجية المباه

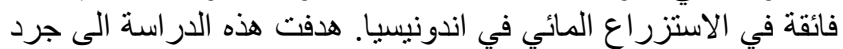

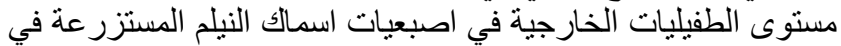

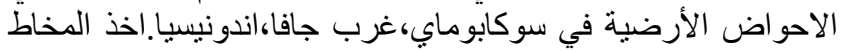

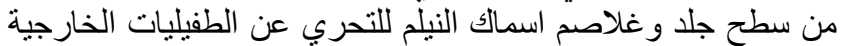

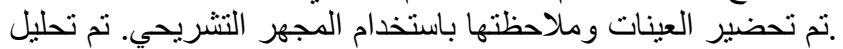

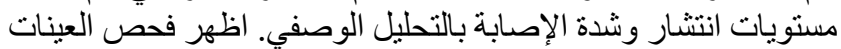

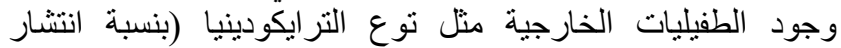

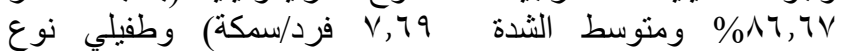

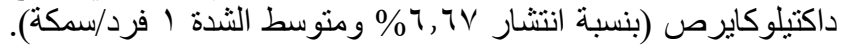

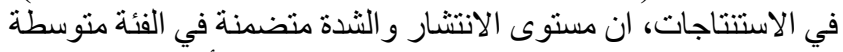
الإصـابة ولا يشكل كلا الطفيليين خطر الأنئ حيو الني المنشأ. 